\title{
CRENÇAS E PROMESSAS NAS TRAVESSIAS DA VIDA
}

\author{
Maria Engrácia Leandro \\ José Pinto ${ }^{1}$
}

Foi na Senhora do Amparo. No meio da capelinha apinhada de gente, subi acima de um mocho, e encomendei a miséria humana à misericórdia divina. Tinha a impressáo que falava realmente com Deus, e de que ele me ouvia, obrigado pela conviç̧ão que eu punha no que lhe dizia [...].

(Miguel Torga, A criação do mundo)

Resumo: Este artigo, apoiando-se numa reflexão teórico-empírica, visa estudar o fenômeno das promessas às forças sobrenaturais, tomando como terreno de pesquisa três regiōes diferentes: duas em Portugal e outra na região parisiense, cujas dinâmicas econômicas, sociais, culturais e religiosas integram semelhanças e distinçôes. Tendo presente uma menor influência da religião nas sociedades hodiernas e, ao invés, uma procura do sagrado logo que as vicissitudes da vida se manifestam, procuramos analisar as singularidades das atitudes votivas. Para estudar estas interferências, damos particular importância ao alcance das transmissóes familiares votivas, à solidez das devoçóes quando outros recursos não se afiguram fiáveis, colocando em cena as noções de crença e de fé nos entes sobrenaturais, e aos mecanismos de transformação em curso acerca deste fenômeno social.

Palavras-chave: Crenças; Entes Sobrenaturais; Potência; Promessas; Transmissóes Familiares.

1 Maria Engrácia Leandro é investigadora do CIES-ISCTE - Instituto Universitário de Lisboa, Portugal. E-mail: maria.eng.leandro@gmail.com. José Pinto é investigador no Arquivo Municipal de Arcos de Valdevez, membro do Grupo de Estudos e Pesquisa em Educação, Religião, Cultura e Saúde (GEPERCS) da Universidade do Estado da Bahia (UNEB), Brasil, além de coordenador do Centro de Estudos e Pesquisa Interdepartamental em Culturas e Religióes (CEPICR/UNEB). E-mail: pinto.jmp@gmail.com.

Debates do NER, Porto Alegre, ano i9, N. 36, P. 335-363, Ago./Dez. 20 i9 


\begin{abstract}
This article, based on a theoretical-empirical reflection, aims to study the phenomenon of promises to transcendental forces, taking as the research field three different regions: two in Portugal and the other in the Paris region, whose economical, social, cultural and religious dynamics integrate similarities and distinctions. Considering a smaller influence of religion in today's societies and, instead, a search for the sacred as soon as the vicissitudes of life are manifested, we seek to analyze the singularities of votive attitudes. In order to study these interferences, we place particular importance on the scope of votive family transmissions, on the strength of devotions when other resources do not seem reliable, to put into the picture the notions of belief and faith in the supernatural entities, and to the mechanisms of transformation underway over this social phenomenon.
\end{abstract}

Keywords: Beliefs; Supernatural Entities; Potency; Promises; Family Transmissions.

\title{
INTRODUÇÃO
}

Ao falar de crenças e de promessas, da sua relação com a vida e com as forças transcendentes, podemos invocar toda a espécie de males e acontecimentos, dos mais triviais aos mais árduos, sabendo que em qualquer das situações há o compromisso de se cumprir o que se prometeu, após a obtenção da graça implorada. Tal como em qualquer outra circunstância, há a submissão ao cumprimento de um contrato firmado na crença, na confiança quanto à realização de algo objetivo e na palavra dada. Transferida para o domínio do transcendente, cinco pressupostos presidem à essência da promessa: o conteúdo duma situação, a função do religioso implicando a crença no ente sobrenatural e na sua capacidade de resposta adequada, o ato de prometer, a expetativa de ser atendida(o) e o cumprimento do prometido.

Compreende-se que num quadro problemático como este, as promessas tendam mais a surgir quando os males da vida se afiguram difíceis de vencer através dos recursos materiais ao alcance de cada um e da sua envolvência 
familiar e social. Para o efeito, também podem ter grande influência os processos de transmissão e socialização familiar e social, criando entre as geraçôes uma cadeia de santos protetores devocionais, cujas potencialidades já foram asseverados anteriormente.

Frise-se, porém, que o ato de prometer, na esperança de vir a alcançar o solicitado, fundamentando-se na crença na capacidade para intervir da entidade supranatural a quem é dirigido, implica um trabalho de relação e o cumprimento do voto formulado, o que, na linguagem corrente, designa o cumprimento da promessa. Assim, sejam quais forem as circunstâncias, numa lógica de dom e contra dom, dá-se uma garantia decorrente duma afinidade relacional de confiança e de compromisso assumido pelo suplicante que, se esquecido, pode levar à rutura da correspondência biunívoca entre o prometido e o realizado. No sentido religioso ou espiritual propriamente ditos, sobretudo, a nível da religiáo popular, o não cumprimento das promessas poderá ser um mau prenúncio, uma vez que poderá acarretar consequências funestas para os faltosos e até para os seus familiares, podendo atrair a vingança ou a ira dos entes sagrados em questão (Augé; Herzlich, 1984). Daí que, em geral, haja uma séria preocupação em não faltar ao compromisso assumido, inclusive quando náo haja a certeza de ter sido por esta via que o solicitado foi alcançado.

Neste trabalho, focalizados no fenômeno das promessas às forças sobrenaturais, visando alcançar graças que, de outro modo, se julgariam muito difíceis ou praticamente inacessíveis, apoiados numa reflexão teórico-empírica, com recurso a trabalho de campo de índole sociológica, procurámos estudar essencialmente três aspetos. O primeiro analisa as incidências da transmissão familiar e social na formação de um ethos votivo, capaz de acreditar na potência daquele(a) a quem se fazem as promessas e de quem se espera obter as graças solicitadas. O segundo visa destacar a relação entre situações difíceis da vida e o surgimento das promessas. Segundo Durkheim (1960), circunstâncias há em que a fé confere força para agir. Enfim, o terceiro, tendo presente as dinâmicas religiosas, sociais e culturais em curso, procura apreender as principais vertentes destas vivências.

Debates do NER, Porto Alegre, Ano i9, N. 36, P. 335-363, Ago./Dez. 20 i 9 


\section{QUESTÓES METODOLÓGICAS}

$\mathrm{Na}$ linha de orientação que preside a este trabalho de cariz exploratório, socorremo-nos de técnicas metodologias qualitativas, incidindo na observação direta e na realização de entrevistas semiestruturadas. Partilhamos do ponto de vista weberiano, segundo o qual estudar o social é compreendê-lo, a partir da sua realidade intrínseca e extrínseca.

Numa primeira fase, o trabalho de campo realizado focalizou-se na observaçáo direta junto de algumas famílias e em locais onde a expressáo dos atos votivos é mais notória: ermidas, igrejas, santuários, outros espaços de culto e peregrinação e locais de exposição de ex-votos. Os primeiros passos tiveram lugar em 2014, em plena época de crise económica e social em Portugal, em que se denotava "de novo" uma tendência para recorrer às promessas, inclusive por parte de jovens em busca de emprego e de mais segurança para a vida. Devolvidos dois anos, em Portugal, voltamos de novo ao terreno junto da(o)s mesma(o)s entrevistada(o)s para poder avaliar das permanências e das mudanças produzidas perante o fenômeno em análise.

Por razóes operatórias, mercê das nossas relaçóes de conhecimento do meio, numa ótica comparativa, escolhemos realizar este trabalho no concelho de Braga e no concelho das Caldas da Rainha, o primeiro situado no norte e o segundo no centro/sul de Portugal, na parte designada de Oeste. Aliás, segundo os dados do recenseamento de $2011 \mathrm{em}$ Portugal, trata-se de duas regiôes onde a prática e a influência religiosas são mais intensas, com destaque para a primeira, como os trabalhos de Teixeira (2011) também o vieram a confirmar. Frise-se, todavia, que este era náo um fator fundamental da nossa escolha sociogeográfica.

Pois bem: porque de uma escolha comparativa se tratava, quisemos, ainda, alargar este trabalho à região parisiense, onde anteriormente já tínhamos realizado extenso trabalho de pesquisa, junto da coletividade portuguesa ${ }^{2}$

2 Note-se que entre 1960-1973, cerca de um milhão de portugueses veio para França em busca de melhores condiçóes de vida. Destes, 345 940, em 1975, e 333 680, em

Debates do NER, Porto Alegre, ano i9, N. 36, P. 335-363, Ago./Dez. 20 i 9 
(Leandro, 1995). Numa perspetiva longitudinal, procurámos, apreender as novas dinâmicas que se foram produzindo no decorrer do tempo em termos das vivências dum ethos religioso votivo, muito orientado para entes sagrados inscritos numa linha genealógica familiar, por vezes à mistura com outros mais iminentes na sociedade francesa. Tanto mais que as novas geraçôes de portugueses neste país tendem a alinhar-se mais pelos valores da cultura francesa mais racionalizada, urbanizada e secularizada.

O que podemos dizer com estas escolhas espaciais e este conjunto de elementos pré-definidos, é que nos propiciaram um terreno propício à realização de um conjunto de entrevistas semiestruturadas capazes de nos permitirem uma melhor compreensão do fenômeno religioso votivo, do seu significado, das práticas e das crenças que lhe subjazem.

Até porque a postura de investigação compreensiva apoia-se na convicção de que os humanos não são simples portadores de estruturas, mas produtores ativos do social, por conseguinte depositários de um importante saber que se trata de apreender intrinsecamente através das suas práticas e dos seus valores (Weber, 1992). Sociologicamente, o que pretendemos é uma explicação compreensiva do social.

No nível em que nos situamos, importa agora dizer que procedemos à elaboração de um guião de entrevista que, além das variáveis sociais: idade, género, escolarização, profissão, situação perante o emprego, estado civil e posição perante a religião, contem um conjunto de questôes semiabertas sobre os processos de socialização familiar, de forma a poder relevar a importância outorgada às devoçóes familiares de cariz religioso votivo ou similar, e o modo como são reinterpretadas em função das necessidades pessoais, familiares ou outras. Não menos importantes, são as questôes que se prendem com o conteúdo das promessas propriamente ditas e o alcance de que se revestem

1982, residiam na região parisiense. De notar que, inicialmente, a organização religiosa entre os portugueses neste país foi essencialmente promovida pela Igreja portuguesa (Leandro, 2005).

Debates do NER, Porto Alegre, ano i9, N. 36, P. 335-363, Ago./Dez. 20 ig 
em todo este processo. Finalmente, juntámos ainda questôes abertas de cariz projetivo, dando azo à expressão dos ensejos dos nossos interlocutores.

Em termos de amostra, importa frisar que não tivemos a preocupação de selecionar qualquer amostra de tipo estatístico representativo, mas antes proceder à "construçấo progressiva de uma amostra" (theoretical sampling, Glaser; Strauss, 1967), cujos elementos fossem portadores de experiências diferentes ao nível do social e de visóes diversificadas das mesmas realidades em estudo. Trata-se, pois, de uma amostra reduzida, constituída por 15 mulheres e 12 homens, repartidos pelos três espaços selecionados: 6 M. e 4 $\mathrm{H}$. no concelho de Braga, o mesmo na região parisiense e $3 \mathrm{M}$. e $2 \mathrm{H}$. no concelho das Caldas da Rainha ${ }^{3}$, com idades compreendidas entre os 21 e os 68 anos. Possuem graus de escolarizaçáo que vão desde a antiga 4. ${ }^{a}$ classe à licenciatura, cujas situaçôes civis sấo diversificadas, bem como a sua condiçáo perante o emprego, estando algumas/alguns em situação de aposentados.

A realização das entrevistas, anteriormente acordada com os nossos interlocutores, em alguns casos teve lugar na sua própria casa, noutros nas proximidades dos locais de trabalho, sendo de destacar o caso da(o)s feirantes, nas cidades de Braga e das Caldas da Rainha, em horas que lhe fossem mais convenientes. Na região parisiense, todas as entrevistas foram realizadas em casa da(o)s entrevistada(o)s. Como técnica de registo da informação recolhida, recorremos ao uso do gravador, depois de obtida a respetiva autorizaçáo e garantidas as regras de anonimato, e à tomada de notas.

Por fim, através da análise de conteúdo, procedemos ao tratamento da informação recolhida que nos forneceu elementos importantes e significaçóes pertinentes sobre a problemática que estudamos. O trabalho que a seguir prosseguimos, até por razóes de extensão, não espelha todos os dados recolhidos, mas apenas os que se afiguram mais pertinentes para este trabalho.

${ }^{3}$ Esta desigual distribuição também é tributária duma desigual extensão sociogeográfica e demográfica das áreas de estudo selecionadas, ainda que não nos deixássemos guiar por critérios de representatividade estatística.

Debates do NER, Porto Alegre, ano i9, N. 36, P. 335-363, Ago./Dez. 2019 
A este respeito, a observação das práticas, a expressão dos elementos simbólicos e os dados das entrevistas, permitindo estudar as circunstâncias, as representaçóes e as dinâmicas sociais em curso, tanto sob o ponto de vista religioso como social e familiar, relevam algumas perspetivas e dimensóes fundamentais acerca destas problemáticas. Entre elas, destacam-se a importância da transmissão familiar, a permanência de crenças tradicionais nos entes sobrenaturais e o significado dos respetivos locais de culto, embora sujeitos a várias formas de recomposição e reatualização de um ethos votivo como recurso, logo que as situaçóes o exijam e as próprias dinâmicas do acreditar se conjuguem com estes elementos.

\section{TRANSMISSÃO FAMILIAR E SOCIAL VOTIVA}

Transmitir a vida em todas as suas dimensôes significa lutar contra uma prática mortífera de uma temporalidade irreversível, que parece tudo transportar consigo. A morte atinge todos e tudo o que tem vida, inclusive as próprias culturas e civilizaçóes (Thomas, 1988). Os historiadores lembram-nos que civilizaçóes poderosas se afundaram ao longo do tempo, esgotando os seus recursos: a Mesopotâmica (3700-1600 a. C), a Grega (770-30 a. C), a Romana (500 a. C. a 500 d. C.), a Maia (200-900 d. C), a dos habitantes da ilha de Páscoa (700-1700 d. C.), entre outras (Broswimmer, 2003).

Contudo, a vida continua a perpetuar-se, sendo continuadamente renovada e transmitida pelas geraçóes de todos os seres vivos precedentes. Este processo transporta consigo os milhares de dimensóes que a vida contém, inclusive da própria cultura onde se inscreve, e revela a sua fecundidade e criatividade, continuando a assegurar a construção e solidificaçáo de memórias familiares, sociais e religiosas. Quanto à família, a transmissão entre geraçóes engloba essencialmente a vida humana, os cuidados, os afetos, os bens, os valores, as crenças, os saberes, as representaçóes e daí por diante tudo o que se lhe possa associar. Em síntese, a transmissão consiste em situar cada novo ser humano num mundo, numa cultura e numa sociedade que 
o precederam, como uma totalidade antropológica matricial. Sob diversas formas, esta figuração da vida, simultaneamente histórica, material e cultural, representa este pedestal de humanidade em que assenta todo o exercício de transmissão, na medida em que consiste, antes de tudo, numa atividade humana e cultural (Lévi-Strauss, 1982; Elias, 1973).

Não sendo, hoje, novidade para ninguém afirmar que existe uma intrincada relação entre a natureza e a cultura, toda a prática e viver humano englobam tanto o natural como o cultural e o social. A transmissáo, como prática humana intergeracional, não escapa a estas determinaçóes, bem como toda e qualquer atividade humana, onde se inscreve também a dimensão religiosa. É, pois, possível observar a expressão duma dinâmica de continuidade da humanidade na sua própria vida e devir, pesem embora as grandes mutaçóes e metamorfoses em curso. $\mathrm{O}$ que se procura transmitir e assegurar é a vida, acima de tudo, na sua prossecução em termos de identidade humana e social, contra toda a espécie de morte. Assim sendo, a força da transmissão implica o colocar em trajeto no contínuo das geraçóes, através dos conhecimentos construídos, guardados, modificados, reinterpretados ou inovados, os procedimentos, os valores, as narrativas históricas, os mitos, os sistemas simbólicos, os modos de vida, as experiências, as influências sociais, as próprias mudanças e assim por diante.

No que se refere às relaçôes com o sagrado, muito frequentemente as práticas familiares e sociais ancestrais reiteram um pacto entre uma personagem legendária e um território, que asseguram um suplemento de força, saúde, proteção e mais energia, quando dela se tem necessidade. Não admira, que no seio da cadeia intergeracional, as pessoas continuem a dirigir-se a forças sagradas de caráter familiar, qual semelhança com os penates do tempo dos Romanos. Alguns extratos de entrevistas realizadas atestam estas asserções.

Não sou muito de ir à igreja. Mas não falto à peregrinaçâo anual ao $S$. Bentinho da Porta Aberta, para lhe agradecer a ajuda e voltar a pedir proteçáo para a saúde, para a família, o emprego e para a vida em geral. Se não vier, parece que 
a vida já não corre tão bem. Desde muito novo que me habituei a acompanhar os meus pais nestas cerimónias e quero continuar a fazê-lo (H., 47 anos, 9. ano, funcionário público, casado).

Não vou à missa todos os domingos ou coisa assim. Mas venho sempre à festa de Nossa Senhora das Mercês para lhe agradecer a sua proteção e pedir de novo a sua ajuda para a minha vida e a da minha família. Aprendi estas coisas com os meus pais e os meus avós e mesmo agora, que já não resido na freguesia, continuo a vir aqui todos os anos (M., 42 anos, $6 .^{\circ}$ ano, empregada no comércio, casada).

Na minha família, antes de ir para França, já se ia a Fátima. Mas como o dinheiro era pouco, eu só vim duas vezes. Íamos mais ao Senhor do Monte, uma tradição que já vinha dos meus avós. Agora, quando venho a Portugal, procuro ir aos dois lados, para agradecer a proteção recebida durante o ano, sobretudo, para a saúde, para os meus filhos e o trabalho e pedir nova ajuda, coragem e fé para continuar. Assim, sinto-me mais protegida com a minha família (M., 64 anos, $4 .{ }^{a}$ classe, empregada doméstica, casada, e/i/migrante).

Nestes como noutros casos estudados, o desejo de assegurar uma continuidade herdada dos antepassados, visando afastar ou fazer desaparecer o mal, é muito forte. Os devotos, à semelhança dos seus progenitores, dirigem-se aos mesmos entes sagrados, frequentam os mesmos lugares, esperando uma interferência eficaz do sobrenatural, associada a uma preservação e suporte moral, coragem, confiança, estabilização, cura duma doença ou melhoria da saúde, em suma, uma vida sem problemas de maior. A peregrinação, organizada exteriormente ou por iniciativa própria, e a visita aos locais sagrados familiares, para além de assegurarem uma continuidade na memória genealógica, afirmam também a sua vocação terapêutica, quer curativa quer preventiva, e um recurso de proteção e confiança para a vida quotidiana.

Analogamente, estas visitas, podendo não obedecer a datas precisas, tendem, porém, a inscrever-se em dimensóes temporais e espaciais, correla- 
cionadas com calendários litúrgicos e festividades que convocam anualmente muitos dos habituais frequentadores destes espaços sagrados. Acontece, assim, com as peregrinaçôes a Fátima durante os dias 13 de maio a 13 de outubro, mas também com as festividades e cultos locais, na sequência de tradiçôes religiosas e sociais. Tal não impede que todos guardem simultaneamente a devoção e a crença nas potencialidades dos santos e de Nossa Senhora das localidades que lhes são mais próximas e familiares, práticas em que foram precocemente socializados.

Gosto muito de ir a Fátima. Mas, quando vou a Portugal, também vou sempre à Senhora da Agonia, o que já fazia com os meus pais e irmãos, para agradecer as graças recebidas e pedir proteção para a vida e para os meus filhos (H., 64 anos, $4 .{ }^{a}$ classe, mecânico, casado, e/i/migrante).

Desde muito nova que me habituei a ir com os meus pais e irmãos ao santuário do Senhor Jesus do Bombarral de quem sou muito devota. Nunca lhe pedi nada que não mo concedesse. Quando tive um filho bastante doente, fiz uma promessa que cumpri escrupulosamente. Cada vez que venho aqui, sinto-me bem e saio daqui com outras forças. Os meus filhos também nos acompanham, sobretudo, por ocasião dos círios. Pelo menos transmitimos-lhes o que aprendemos com os nossos pais... (M., 49 anos, $4 .^{a}$ classe, comerciante, casada).

Não sou praticante regular, mas tenho fé... Sou muito devota de Nossa Senhora do Sameiro e de Santo António, que é muito venerado na nossa terra, o que já aprendi com a minha família. Nunca lhes pedi nada que não fosse alcançado (M., 38 anos, 9. $0^{\circ}$ ano, funcionária pública, casada).

Compreende-se, deste modo, que tal santo, tal imagem, tal ícone, tal Nossa Senhora são protetores em que acreditam aqueles que vivem na sua área geográfica de proteção e imunidade. Há forças sagradas protetoras de entre as quais a memória coletiva seleciona apenas as que mais lhe convém, dado que, ao longo do tempo e das geraçóes, se têm mostrado mais eficientes 
e familiares. Se, em qualquer destas situações, a crença e a devoção dos fiéis podem ultrapassar fronteiras de proximidade, como acontece grandemente com Fátima em Portugal e Lourdes em França, é a este nível que elas se afiguram mais alicerçadas em socializaçôes familiares anteriores.

Em termos familiares votivos, se as visitas ou peregrinaçôes a espaços mais emblemáticos, ou a locais mais próximos, podem revestir-se igualmente de uma dimensão festiva, nem por isso deixa de se afirmar a sua vocação protetora e terapêutica, extensiva a outros imponderáveis da vida. Em todo o caso, segundo a(o)s nossa(o)s interlocutoras/es, as visitas aos locais sagrados mais familiares e o recurso ao religioso de quem se espera obter graças afiguram-se indiscutíveis.

$\mathrm{Na}$ esteira de Gauchet (1998), podemos dizer que o cerne deste tipo de comportamento religioso é mais o da procura de respostas para as vicissitudes da vida do que da religião, enquanto orientação para a vida, em sentido mais amplo. No âmago deste processo de transmissão, em termos religiosos, está o modo como as diferentes geraçóes se apropriam destes recursos, sendo que as mais jovens, embora menos praticantes, nem por isso deixam de se inscrever numa continuidade genealógica, logo que se trate de promessas ou pedidos às forças sobrenaturais.

Procedimentos desta índole manifestaram-se identicamente nas três regiốes de estudo. Mas vale a pena referir que foi na regiáo parisiense que se denotaram mais inovaçóes, em termos devocionais. Se Nossa Senhora de Fátima, Santo António e outros santos locais portugueses continuam a ser objeto de devoção, culto e súplica, também aparecem novas figuras sagradas. No âmbito do catolicismo, o destaque vai para Nossa Senhora de Lourdes e para Santa Teresinha do Menino Jesus, mais relacionadas com a cultura francesa. Fora deste quadro, mercê de um processo de aculturaçáo de proximidade decorrente de novas relaçóes interpessoais, importa relevar um novo culto em torno do busto de Allan Kardec, fundador do espiritismo, sepultado no cemitério do Père-Lachaise, em Paris. Este lugar de inumação tornou-se objeto de um culto de índole popular, à margem de qualquer intervenção da hierarquia religiosa, cuja devoção se ordena, em primeiro

Debates do NER, Porto Alegre, ano i9, N. 36, P. 335-363, Ago./dez. 20 i 9 
lugar, sobre a dimensão "milagrosa" inerente a este espaço, a que se junta, depois, uma experiência peregrina (Aubrée, 2000).

Neste local, é frequente ouvir falar, ou ler nas mensagens deixadas junto do busto do defunto, das experiências dos dons recebidos por sua intercessão. Sáo essencialmente apreendidas como modo de encontro, fundamentado desde as primeiras visitas, uma vez que se depreende que as graças solicitadas foram atendidas. Pode náo se tratar de um milagre, como aliás poderá acontecer com outros entes sobrenaturais. Só que, para estes crentes, há aqui precisamente o assumir de uma dimensão da ordem do extraordinário que, concebida como tal, produz os seus efeitos. O que está aqui em questấo é um certo tipo de adesáo da ordem da crença, que assenta, em primeiro lugar, numa lógica pragmática, ou seja, na dimensão e eficácia da potência da entidade invocada.

Entre os portugueses a viver na regiáo parisiense, não sendo muitos a aderir a este culto e rituais, encontrámos alguns que aderem a este fenômeno. As pessoas com quem falámos a este propósito, podendo até ignorar a doutrina espiritista, nem por isso acreditam menos na potência deste ente sagrado. As experiências que lhes vão sendo relatadas pela sua nova envolvência social despertam nelas náo apenas curiosidade, mas vontade de se dirigirem a este local e praticarem os respetivos rituais, esperando, deste modo, alcançar os benefícios que procuram. Denota-se, todavia, uma tendência para agirem de modo sincrético: esta nova descoberta e adesáo náo faz com que abandonem os anteriores entes sobrenaturais devocionais e protetores, como podemos constatar nas palavras das nossas entrevistadas:

Não costumo ir regularmente à igreja ou à missa aos domingos. Vou quando sinto necessidade. Mas na véspera dos exames na universidade, eu ou a minha mãe vamos pôr uma vela a arder na basílica de Nossa Senhora de Fátima em Paris XIX e deixar também uma prece junto do busto de Allan Kardec no cemitério do Père-Lachaise. É verdade que estudo e trabalho bastante. Nunca reprovei em nenhum exame. Mas assim sinto-me mais segura e protegida (M., 21 anos, estudante universitária em Paris, solteira). 
$\mathrm{Na}$ nossa vida já vivemos situaçóes muito difíceis que não têm só a ver com doenças. Desde pequena que, na minha família, sem ser muito religiosa, se faziam promessas a Nossa Senhora, a S. Brás e a Santo António. Aqui, quando sinto necessidade, continuo a fazê-lo. Mas também aprendi com a minha patroa e algumas amigas a recorrer a Allan Kardec. Quando sinto que alguma coisa se torna mais complicada, também vou ao cemitério do Père-Lachaise, para pedir a sua ajuda e estou certa que me tem valido (M., 63 anos, $4 .^{a}$ classe, porteira, casada).

O que podemos dizer com estes e outros dados é que estamos perante processos de aculturação religiosa sincrética de ambas as gerações em presença, em que elementos da cultura religiosa anterior, sem se anularem, se articulam com outros da nova cultura, procurando objetivos práticos e comuns. $\mathrm{O}$ que essencialmente se procura, por estes diferentes meios, é a eficácia da realização do conteúdo implorado, quer seja objeto de promessa quer apenas de súplica. Nos casos estudados as promessas inscrevem-se essencialmente no quadro de uma transmissão familiar votiva, fazendo apelo ao dom e contra dom, ao passo que a súplica não implicando, a posteriori, a entrega de uma dádiva tem mais a ver com novas entidades sacrais, como aparece claramente na relação com Kardec. Como o faz notar Menezes (2004), a relação de gratuidade numa e noutra situação, configura significados distintos com os entes sagrados em questão: o pedido implica agradecimento e a promessa pagamento.

\section{QUESTÃO RELIGIOSA, QUESTÃO VOTIVA NAS SOCIEDADES HODIERNAS}

Embora a religião tenha sido uma matriz social, política e cultural e uma força civilizadora do ocidente, com o avançar da modernidade laica e racional, foi perdendo influência social, tendendo a ficar mais confinada a certas dimensóes culturais da sociedade e da vida privada dos indivíduos. Neste processo, foi deixando de ser uma religião de massas, assim como 
fator modelar das consciências e dos comportamentos sociais. Assim sendo, as designadas teorias da "secularização" (pensamento anglo-saxónico) e da "laicização" (pensamento francês), falando de sociedades secularizadas ou laicizadas, colocam a tónica num muito menor impacto da religiáo nas sociedades modernas (Martin, 1969; Certeau; Domenach, 1974). Estas asserçôes dáo-nos conta de um jogo de soma nula: quanto mais a modernidade avança, menos o impacto da religiáo se faz sentir, nas várias dimensôes da vida privada, pública e social. Gauchet (1985) fala mesmo de uma modernidade "desencantada".

Não obstante, por volta dos anos 1970, numa situação de acentuada crise social e económica, assiste-se à reemergência do religioso, avançando de modo manifesto novas crenças e práticas rituais mais consentâneas com os valores da modernidade, em princípio governada pela ciência e pela tecnologia, ao mesmo tempo que a religiáo islâmica e o budismo alcançam novo vigor. Há, ainda, um impulso extraordinário de espiritualidades de vária índole, muito frequentemente à margem da religiáo institucional, e de uma religiáo de cariz emocional, cujo paradigma pode ser colhido na proliferaçáo das novas religiốes, nos movimentos carismáticos ou similares, inclusive no seio da Igreja Católica, em busca de mais bem-estar do corpo e da mente.

Para explicitar, teoricamente, $\mathrm{o}$ alcance de tais fatos, vale a pena evocar a definição de Durkheim (1960, p. 65) segundo a qual "Uma religião é um sistema solidário de crenças e de práticas relativas às coisas sagradas, isto é, separadas, interditas, crenças e práticas que unem numa mesma comunidade moral, chamada Igreja, todos os que aí aderem". Esta definição pôe em destaque dois critérios complementares. $\mathrm{O}$ fenômeno religioso é à partida apreendido a partir das noçôes de sagrado e de profano que se opóem de maneira irredutível, designando dois mundos incomensuravelmente separados: as coisas sagradas são as que os interditos protegem e isolam; as coisas profanas são aquelas a que não se aplicam estes interditos e que devem permanecer distantes das primeiras. O sagrado é, por conseguinte, o que é inacessível ao profano. 
Este esforço reflexivo conduz-nos a outra oposição do autor entre o "sagrado transcendente" e o "sagrado imanente". Trata-se no primeiro caso de algo que é exterior e se eleva acima da sociedade, e no segundo o que é forjado por si própria em seu favor. Para ilustrar este último ponto, considera que nas sociedades modernas, a criação de grandes ideais coletivos, sobretudo, em épocas revolucionárias, traduz uma atitude da sociedade para erigir em "Deus" ou criar deuses que vêm a ser transformados pela opiniáo pública em coisas sagradas.

Fenômenos desta natureza não são menos comuns nas sociedades hipermodernas produtoras que são de muitas formas de "sagrado imanente", como tem vindo a acontecer, por exemplo, com a busca da saúde perfeita, do bem-estar, da riqueza ou do sucesso. Só que nem sempre as coisas correm de feição, designadamente para os grupos de condição social modesta.

Por outro lado, com novas configuraçóes do religioso, como se tem vindo a observar, vale a pena destacar o fato dos indivíduos se permitirem forjar os seus próprios sistemas de crença, alguns fora das referências de um corpo de crenças institucionais. Porém, não deixam de considerar Deus e os entes sagrados das suas devoçóes como "uma força superior" que pode vir em seu auxílio.

Não menos importante é o fenômeno do que podemos designar de "peregrinaçôes terapêuticas", cujos casos paradigmáticos poderão ser recolhidos, por exemplo, em Lourdes (França), Sainte Anne de Beaupré (Canadá), Senhora da Aparecida (Brasil), Virgem Negra (Polónia), ou em Fátima, (Portugal) (Leandro, 2001). Em várias circunstâncias, designadamente de doenças mais ou menos graves, constata-se que o recurso ao santo protetor se torna mesmo um meio para as gerir, em busca da cura almejada.

Este conjunto de elementos, vindo a revelar novas formas de relacionamento com os entes sagrados e o sagrado em geral, levaram vários autores e estudiosos a falarem do "regresso do religioso", o que exige algumas precauçóes, uma vez que estes novos movimentos religiosos náo são uma reprodução pura e simples do religioso anterior (Hervieu-Léger, 1999). Em contrapartida, quando têm vindo a surgir vários tipos de crise, as incertezas

Debates do NER, Porto Alegre, Ano i9, N. 36, P. 335-363, Ago./Dez. 20 i 9 
quanto ao futuro se intensificam e a pressão para a mudança é intensa, mais, as crenças proliferam, diversificando-se e multiplicando-se indefinidamente (Vilaça, 2006). Por sua vez, os locais votivos de peregrinação ou de romarias, onde se destacam santos ou imagens de Nossa Senhora, a quem se atribuem poderes milagrosos, continuam em alta.

Grosso modo, trata-se de uma busca positiva, uma preocupação de harmonia que Lambert (1985) define como uma "positivização", ou seja, um processo dialético de manutenção e melhoria, por oposição ao que pode ser a degradação, quer se trate da saúde, quer da felicidade e do bem-estar. Incansavelmente, embora em circunstâncias diferentes, os humanos sempre se dotaram de meios para conservar este equilíbrio, no decorrer dos tempos. E se a ciência e a racionalidade são mais notórias nos nossos dias, se a causalidade, a explicação dos fatos sociais pela ciência entraram diretamente em concorrência com as ideologias religiosas, desqualificando a intervenção divina, também não têm podido resolver tudo, abranger tudo, designadamente o espaço do incalculável, do imprevisível e do acaso.

\section{PROLONGAMENTO DOS SÍMBOLOS VOTIVOS}

A água, o círio, a imagem, a medalha, o terço, ou outro objeto que se possa levar dos locais de devoção e de cumprimento de promessas, são imbuídos de uma alquimia que se acredita poder prolongar e atualizar o poder e ação que irradia destes locais, através da veneração do ente sobrenatural, cujo símbolo pode ser colocado em espaços muito peculiares, normalmente de grande visibilidade, como aliás os antepassados já o poderiam ter feito. Trata-se de uma praesentia, isto é, uma presença física do sagrado, que protege e salva dos perigos que possam espreitar daqui ou dali. Dá-se, assim, expressão a um habitus, que revela e assegura uma devoção quotidiana, intensamente renovada para lá dos locais e momentos excecionais de súplica e de assunção de compromissos. 
Neste sentido, pelo menos simbolicamente, como nos disseram alguns dos nossos interlocutores, ainda com maior ênfase em contexto migratório, procura-se asseverar uma proteçáo atemporal e desterritorializada, pois se acredita nela na vida do dia-a-dia. Em muitas casas dos portugueses, em França e na Alemanha, de mistura com alguns símbolos nacionais, as imagens de Nossa Senhora de Fátima e do(a) santo(a) protetor(a) da aldeia são colocados em espaços bem visíveis. Porém, nos momentos fortes há necessidade de reafirmar a fé e voltar a praticar ritos de intercessão e de reconhecimento. As idas a Fátima dos migrantes portugueses nos períodos de férias, dentro ou fora das peregrinaçooes organizadas, são paradigmáticas a este propósito. Colocar um ramo de flores, uma vela ou outro objeto de cera, uma mensagem, andar de joelhos, entregar o valor monetário da promessa ou outra forma de dádiva, trazer uma medalha ou outro ícone sagrado, constitui, inevitavelmente, uma demonstraçáo da fé depositada no ente sagrado da sua devoção e na sua capacidade de intervenção.

Em termos de crença, essa prática possibilita também aos outros reafirmar fundamentos suplementares aos seus. Aqui se agradece e aqui se volta a implorar proteção para os males do corpo e da vida, em geral, ora cumprindo promessas e agradecendo, ora voltando a renová-las, designadamente quando não são consequência de situações difíceis, mas se relacionam com o percurso da existência, como nos revelam algumas/alguns da(o)s nossa(o)s entrevistada(o)s.

Já fiz algumas promessas, em situações de doença, a Nossa Senhora de Fátima e a Nossa Senhora de Lourdes. Mas foi de Nossa Senhora de Lourdes que obtive as graças que lhe pedi e que na altura bem precisava. De Fátima, pela minha experiência e da minha família, nunca recebi nada de extraordinário. Talvez por isso, sinta que é mais uma devoção que me leva quando lá vou a pedir a proteção de Nossa Senhora para a vida, mas sem prometer isto ou aquilo. Claro que dou uma esmola ou ponho uma vela por cada um dos meus filhos, pelo grupo de jovens com quem trabalho e assim..., pedindo a Nossa Senhora que os proteja, mas só por devoção. Depois até parece que a vida corre melhor (M., 66 anos, $4 .^{\text {a }}$ classe, aposentada, casada, imigrante). 
De vez em quando gosto de ir a Fátima. Só fui uma vez para cumprir uma promessa que a minha mãe tinha feito por mim, quando fazia o serviço militar em Moçambique. Quando lá vou sinto-me bem e parece que venho de lá com mais força para a vida (H., 67 anos, $4 .^{\mathrm{a}}$ classe, operário, aposentado, casado, imigrante).

Nas minhas orações também faço menção a Deus e a Nossa Senhora, das minhas preocupações e do que gostava que concedessem a mim e à minha família. Entâo, quando a doença aparece, ainda o faço com mais fé. Chego mesmo a ir a Fátima e ao Bom Jesus do Bombarral, pois são lugares onde sinto a sua intercessão de maneira diferente (H., 54 anos, $9 .^{\circ}$ ano, funcionário público, casado).

Trata-se, nestes casos e noutros semelhantes, não tanto de promessas, mas de atos antecipadores, sob a forma de súplica, comprometendo também as forças sagradas a estarem permanentemente atuantes no decorrer das circunstâncias da vida quotidiana. Podemos mesmo dizer que os rituais de súplica, os ritos peregrinos, a veneração das relíquias, o uso de medalhas ou outros símbolos sagrados, não sendo uniformes, tendem a variar e a adaptar-se às circunstâncias.

\section{ATOS VOTIVOS E EXPERIÊNCIA PEREGRINA}

A experiência peregrina, contendo a noção de encontro talvez habitual e recorrente, que pode ou não ter lugar em função de promessas, também pode incluir outras modalidades. Basta invocar a (re)emergência das peregrinaçôes ou simplesmente caminhadas a pé a locais reconhecidos de culto, para implorar, agradecer ou, simplesmente, para que aqueles que as praticam se sintam bem consigo mesmos. Importa, porém, dizer que, muito frequentemente, uma trajetória desta natureza, podendo ou não incluir promessas, pode começar por um movimento interior surgido em conversa com alguém, ou após a obtenção de uma graça sem que antes tenha dado 
azo a compromissos concretos, como são os atos de promessa, normalmente em correlação com uma presença sagrada, asseverada neste ou naquele local, e com uma tradição de experiências peregrinas.

Compreende-se, aliás, que as caminhadas a locais de peregrinação, podendo ser apenas alicerçadas em buscas de mais saúde e bem-estar face ao aumento do stresse e outras "doenças da civilização", tenham vindo a (re)ganhar novo fôlego (Leandro, M.; Leandro, A., 2015). Acontece, contudo, que, quando o pedido ou desejo são alcançados, o crente agraciado tende a tornar-se mais firmemente consciente da eficácia do ente sobrenatural e tem mais probabilidades de ir construindo um habitus de crença, devoção e experiência peregrina votiva, ainda que possa ser apenas para se sentir melhor consigo mesmo e com a vida.

Importa sublinhar que, na lógica de uma maior individualidade da própria relação com as forças sagradas, muito frequentemente, nas sociabilidades peregrinas, não há propriamente uma comunidade que seja percetível e com a qual os peregrinos se sintam comprometidos. Há, quando muito, um ajuntamento de pessoas que mudam de uma vez para a outra, tendentes a partilharem experiências, que podem vir a pesar na elaboração das próprias crenças e nas dos outros, com os quais se sente formar uma unidade pontual. Nestes encontros há a procura da prova e a manifestação da realização da prova, o que favorece a crença no ente sobrenatural que concedeu o favor solicitado.

Por outro lado, pelo menos no contexto ocidental da atualidade, a procura de provas sagradas e da sua eficácia traduz-se numa crença na existência da clemência de Deus, que motiva os fiéis através da mediação do seu santo protetor. É esta crença que se procura solidificar. Os santos, os entes sobrenaturais não têm poder por si próprios, mas porque participam de algo divino. Por detrás de um ente intercessor está Deus, embora para os que fazem as promessas a graça emane daquele(a) a quem se dirigem.

Por sua vez, para quem intercede, designadamente em situação de absoluta necessidade, seja qual for a sua índole, os sacrifícios, as ofertas, os dons decorrentes das promessas, longe de subtraírem todas as misérias,

Debates do NER, Porto Alegre, Ano i9, N. 36, P. 335-363, Ago./Dez. 20 i9 
pelo menos no imediato, podem juntar eficácia à oraçáo ou à promessa, o que parece assumir ainda outro significado, quando realizado em locais de peregrinação. $\mathrm{O}$ seu valor depende não da pura entrega dos dons ou de atitudes místicas, mas da reserva digna de intensidade de elevação do espírito para Deus e outras forças sobrenaturais que estes lugares proporcionam (Bonnet, 1977).

Olhando mais de perto a realidade, constata-se que a crença na potência que é tida como potenciadora da graça, do milagre, tende a ser muito forte, o que motiva ainda mais os crentes a dirigirem-se aos locais onde ela se encontra, quer para suplicarem, quer para agradecerem, cumprirem a promessa e voltarem para casa mais confortados. Basta estar atento e reparar na importância que esses crentes atribuem às imagens, através do olhar e do toque, até quando nas igrejas os comungantes regressam para os seus lugares. A importância do toque e do olhar, dirigido e fixado na imagem que é objeto de súplica ou de agraciamento é aqui grandiloquente. $\mathrm{O}$ olhar face a face concede uma sensação de interlocução quase material (antropomorfismo), o que explica um fenômeno relacional entre a força sagrada e os que se the dirigem personalizando-se. Por sua vez, o toque coloca diretamente em movimento a potência da imagem. Através deste gesto, procura-se sobretudo recolher uma força carregada de positividade. O indivíduo apresenta-se em situação de busca, mas de dependência e reconhecimento, chegando mesmo a conferir vida às imagens que venera, como refere Lima (2014, 2015), relativamente a devoções sui generis perante diferentes imagens de Santa Rita na igreja do mesmo nome, no Rio de Janeiro.

Do nosso trabalho de observação direta, inclusive junto da sepultura de Allan Kardec, importa ressaltar, igualmente, o fato da procura do momento, para que seja possibilitado o toque individual e náo haja outras interferências ou cruzamentos, evitando ter de confrontar-se com a possibilidade de ter de recolher energias estranhas, quiçá nefastas, vindas de outros. Estes gestos procuram captar energias favoráveis e libertar-se de outras que podem ser menos benéficas. Há aqui uma espécie de permuta que pode conceder ao crente uma sensação de libertação e de concessáo da graça solicitada. 
As imagens são objeto de substituição/representação dos respetivos entes sobrenaturais, assegurando continuidade, retransmissão, mudança e, por conseguinte, um circuito entre sagrado, material, necessidades, recursos, respostas, dom e contra dom. O indivíduo apresenta-se desprovido de meios, mas em situação de busca, dependência, reconhecimento e consolação. Por sua vez, o ente sagrado, também por estes meios, aufere do reconhecimento assegurado da sua potência.

Compreende-se, então, que as imagens sagradas - qual forma de politeísmo - tornem presente fisicamente a força sagrada agraciada ou venerada, pelo que o toque nas imagens revele essencialmente duas dimensóes deste culto: por um lado, devoção e espiritualidade e, por outro, capacidade de daí sair com uma graça, porque se acredita na eficácia intrínseca do poder, energia, força, fluído magnético ou universal aí contido e nos seus espaços diretos de intervenção. $\mathrm{O}$ fato das pessoas quererem contactar diretamente os entes sagrados nos seus próprios locais públicos de veneração também se reveste de alto significado como nos foi revelado pelos nossos interlocutores. Normalmente, não faltam réplicas dos mesmos que os devotos podem inclusive entronizar na sua própria casa. Só que não parecem assumir aqui o mesmo significado, pois se acredita que destes locais de origem cultual coletiva emanam forças diferentes de quaisquer outras, carregadas de positividade, capazes de concederem as graças solicitadas.

\section{PROMESSAS FEITAS, COMPROMISSOS ASSEGURADOS}

Importa frisar que, para os nossos interlocutores, a fé, a crença na potência e a confiança são indispensáveis para que a graça seja obtida e o milagre aconteça. Daí que o ritual das promessas, desde o momento em que são formuladas até ao seu cumprimento, não dispense uma fé convicta e ativa, extensiva às devoçóes, rotinas anuais ou periódicas, (re)encontros, compromissos e esperanças renovadas. É o próprio Jesus Cristo que, na cura da hemorroíssa, afirma: "Minha filha, a tua fé te salvou; vai em paz e 
fica sarada do teu mal" (Mc., 5, 34). Jesus Cristo, não tendo exigido nada em troca do milagre concedido, insiste na atitude de fé. Não obstante, não é apenas a fé que salva. Importa igualmente agir e entrar em relação, o que implica um trabalho de construção da própria crença, capaz de se solidificar à medida que as provas (os "milagres" alcançados) se vão acumulando. Aliás, o recurso aos entes sobrenaturais também é um modo de gerir as vicissitudes que a vida possa conter ou a ajuda que se procura para a melhorar nos mais variados aspetos.

Numa mesma lógica, se o primeiro passo da promessa inscrita numa longa tradiçáo antecipa o acontecimento, cumpri-la também se inscreve num processo de compromisso e gratidáo. Entre os nossos entrevistados, o reconhecimento é geral, ainda que, em alguns casos, se possa instalar a dúvida acerca da mediação solicitada. Mesmo assim, o reconhecimento conduz ao agradecimento, levando a um ato de reciprocidade, numa troca indizível, misturada com respeito e dever moral, podendo haver ou náo receio da puniçáo divina. $\mathrm{Na}$ crença dos nossos interlocutores, o mundo celeste afigura-se muito sensível às dificuldades humanas. Para o agradecer, observam-se ritos, fazem-se oraçóes, ofertas, caminhadas, na continuidade do que enforma o processo da súplica e das promessas.

Deus, Nossa Senhora, os santos não nos pedem nada. Somos nós que lhes pedimos e prometemos ou porque estamos desesperados e não encontramos outro meio para resolver essas situações ou porque acreditamos nos seus poderes e na sua bondade. Por isso, se prometemos, temos de cumprir. Nos casos mais difíceis da minha vida, que foram relacionados com o meu filho, primeiro por motivos de doença quando ainda era criança e mais tarde quando estava na Universidade do Minho e tinha dificuldades em acabar o curso, fiz promessas difíceis de cumprir ao S. Bentinho da Porta Aberta e a Nossa Senhora do Sameiro. Mas cumpri-as à risca, mesmo com dificuldades à mistura... (M., 64 anos, 4. ${ }^{\mathrm{a}}$ classe, comerciante, casada). 
Não sou muito de fazer promessas, até porque já acreditei mais nisso. Mas já fiz promessas, sobretudo, pelos meus filhos. Numas alcancei o que pedi e noutras nem tanto. Mesmo assim em todas cumpri o que prometi.

Ao que retorquimos: se não tinha a certeza, porque quis cumprir?

Porque tinha dúvidas. E quando assim é, prefiro cumprir com o que prometi, mesmo não tendo a certeza. Mas não foi por medo que depois de morta a alma cá viesse, como me ensinavam quando era criancinha na minha família e na aldeia em que vivia. Cheguei a acreditar nisso. Hoje não. Tenho cabeça para pensar. Quando morrer acaba-se tudo [...]. Mas é assim na minha vida: quando prometo alguma coisa, mesmo na dúvida, prefiro cumprir (M., 62 anos, $4 .^{\text {a }}$ classe, feirante, casada).

Vou pouco à igreja, embora quando era criança tivesse ido à catequese e feito as comunhóes todas. Continuo a ser crente. Também não sou muito de fazer promessas e quando faço, é mais em função da família. Quando a minha filha tinha 9 anos, teve uma doença com que os médicos tiveram muita dificuldade em acertar. Então fiz uma promessa à Senhora do Sameiro, que me ouviu. A seguir cumpri rigorosamente o que prometi. De resto, na vida de todos os dias trabalho e procuro ser honesta com toda a gente e náo sou de fazer promessas por isto ou por aquilo (M., 43 anos, $99^{\circ}$ ano, feirante, casada).

Nunca fui muito de fazer promessas. Apenas quando estive no Ultramar fiz uma promessa a Nossa Senhora de Fátima. Cumpri o que prometi e o que a minha mãe prometeu por mim. Prometemos, pagámos porque assumimos um compromisso. E só por isso e mais nada. Mas lembro-me da minha mãe nos dizer quando se sentia doente para não esquecermos de pagar uma promessa de cinco escudos que ela devia em tal lado. Porque nos pedia isto não sei. Será que tinha medo do que lhe poderia acontecer depois da morte? Mas foi ainda ela que os pagou (H., 66 anos, $4 .{ }^{a}$ classe, reformado, casado, imigrante). 
Destes extratos das entrevistas destacam-se três dimensōes essenciais. A primeira tem a ver com a assunção dos compromissos. Efetivamente, é dada uma importância primordial à realização do prometido, mesmo quando a dúvida possa permanecer acerca da intervenção do ente sobrenatural. Trata-se de um ato de confiança recíproca, já que a promessa compromete mais do que descompromete. As relaçôes com as instâncias sobrenaturais - divindades, santos, antepassados, génios... -, não são passíveis de medir e pesar como se de medidas e cálculos humanos simplesmente materiais se tratasse. É preciso ser coerente naquilo em que se acredita, com a crença no ente sobrenatural, com o que se solicita, promete e realiza. A segunda dimensão tem a ver com o fato de as promessas serem mais feitas em função dos familiares do que dos interesses individuais, fazendo notar que a família continua a ser uma entidade gregária, no amplo sentido do termo. A terceira dimensáo tem em conta um processo de continuidade/transformaçáo em curso, sob o ponto de vista das mentalidades acerca dos atos votivos e do seu alcance. De algum modo, nas entrelinhas, aparece uma tendência das mulheres e dos homens modernos e religiosos, em que os fiéis se dividem entre duas posiçóes: mais ou menos praticantes, continuam a acreditar na intervençáo divina, mas continuam mulheres e homens do seu tempo, mais abertos às racionalidades das sociedades hodiernas e às suas influências.

Enfim, para explicitar o alcance de algumas mudanças em curso quanto a alguns significados intrínsecos das promessas, mormente no atinente ao seu caráter de negociação/gratuidade, vale a pena acrescentar, ainda, dois extratos das entrevistas realizadas.

$\mathrm{Na}$ minha família já vivi situações muito difíceis, mas as piores foram de doenças. Numa altura em que o meu marido estava gravemente doente fiz uma promessa avultada, em dinheiro, a Nossa Senhora de Fátima. Só que as dificuldades foram-se acumulando e não tinha condiçóes para a pagar. Falei com o Senhor Padre que me disse que se prometi tinha de cumprir. Ainda bem que me aconselhou a pagar por fases. Disse-me ainda: Oh Senhora X quando tiver problemas não negoceie com Deus que não é comerciante... 
Depois paguei a promessa que tinha feito, mas não voltei a fazer promessas. Quando sinto necessidade de alguma coisa maior peço com confiança e não sinto menos os resultados (M., 63 anos, $4 .^{\text {a }}$ classe, doméstica, casada).

Na minha família havia o hábito de fazer promessas, o que eu também fiz durante um certo tempo. Já há muito que deixei de o fazer. Em Braga, isso continua a ser muito comum. A própria Igreja alimenta este negócio, pois daí retira benefícios. Ora, se Deus é omnisciente, como aprendi na catequese, conhece bem o que necessitamos sem que haja necessidade de negociatas: se me deres isto ou dou-te aquilo. O mesmo acontece com Nossa Senhora e os santos. Só que as pessoas ainda estão muito arreigadas a estas tradiçóes que começam logo a ser aprendidas na família... (M., 58 anos, $12 .^{\circ}$ ano, secretária, viúva).

Destas considerações vale a pena relevar dois aspetos fundamentais. No primeiro caso denota-se uma mudança de atitude de promessa para outra de súplica, através da oração. Em ambas, na relação com outrem de índole sagrada, se procura obter um efeito. Só que na atitude de súplica, a eficácia consiste exatamente no fato de ter sido atendido o pedido, desprovido de pagamento de qualquer contrapartida, como o próprio sacerdote o tinha explicitado. Por sua vez, no segundo caso, sem qualquer forma de substituição, sobressai o descrédito das práticas votivas tradicionais.

\section{CONSIDERAÇÕES FINAIS}

Sejam quais forem as interpretações que se possam fazer do fenômeno das promessas e das suas (i)lógicas, o que podemos dizer, com base nos dados recolhidos, sem qualquer pretensão de extrapolação, é que as promessas às divindades, nas sociedades hodiernas, tratando do comum e do extraordinário, continuam a ser um recurso e um reservatório de forças, mobilizáveis logo que as vicissitudes da vida tal impliquem. Contudo, importa ter presente 
que se denota uma maior tendência para se ter mais em conta elementos de racionalização moderna.

Neste trabalho, relevam-se duas dimensóes essenciais. A primeira prendese com os fenômenos da socialização e da transmissão familiar, fazendo com que as geraçóes mais novas, no atinente às promessas, tenham tendência a invocar a intervenção dos mesmos entes sobrenaturais e a frequentar os mesmos espaços de devoção, culto e peregrinação, logo que se confrontem com vicissitudes da vida mais complicadas. Estas forças sagradas tendem, assim, a ser erigidas em recursos familiares terapêuticos ou protetores de grande alcance, inscritos numa linha genealógica, o que, em termos comparativos, se revelou comum nas regiôes em estudo. Porém, é na região parisiense que se denotam mais inovaçôes, verificando-se alguma tendência para um certo sincretismo votivo ou de súplica.

A segunda vertente relaciona-se com o fato das permanências e mudanças em curso darem azo a novas interpretaçóes de sentido do religioso na vida quotidiana e a novos tipos de práticas religiosas mais fragmentadas, sem no entanto, abolirem crenças e práticas tradicionais, muito concretamente quanto às promessas e súplicas de interceção sobrenatural. Deus e outros entes sagrados continuam presentes na vida daqueles que acreditam nas virtudes das suas intervençóes e nas suas graças, designadamente quando outros meios materiais se afiguram incertos. Recorrer a Deus, a Nossa Senhora, ao santo ou outra entidade sobrenatural, devido a uma doença ou a outro infortúnio da vida, mesmo sem anular outras buscas, pode tornar-se um recurso de gestão conjunta.

Em síntese, pesem embora mudanças em curso, com as promessas buscam-se respostas concretas e céleres. Numa época em que se investe sobremaneira na busca de felicidade e de bem-estar materiais, num éden terreno e de salvação aqui e agora, as pessoas têm muito mais dificuldade em conviver com males de qualquer ordem e ainda mais quando se relacionam com a doença, o desemprego, ou outros infortúnios. Quando assim acontece, são capazes de mobilizar todos os meios ao seu alcance para modificarem a situação, inclusive por meio do recurso às forças transcendentais. 


\section{REFERENCIAS}

AUBRÉE, Marion. La nouvelle dynamique du spiritisme kardéciste. Ethnologie française, Paris, v. 30, n. 4, p. 591-599, 2000.

AUGÉ, Marc; HERZLICH, Claudine (org.). Le sens du mal. Paris: Archives Contemporaines, 1984.

BONNET, Serge. La fête, la réligion populaire et le clergé. Nancy: Presses Universitaires de Nancy, 1977.

BROSWIMMER, François. Une brève histoire de l'extinction en masse des espèces. Paris: Parangon, 2003.

CERTEAU, Michel de; DOMENACH, Jean-Marie. Le Christianisme éclaté. Paris: Seuil, 1974.

DURKHEIM, Émile. Les formes élémentaires de la vie religieuse. Paris: PUF, 1960.

ELIAS, Norbert. La civilisation des moeurs. Paris: Calmann-Lévi, 1973.

GAUCHET, Marcel. La religion dans la démocratie: parcours de la laïcité. Paris: Gallimard, 1998.

GAUCHET, Marcel. Le désenchantement du monde: une histoire politique de la religion. Paris: Gallimard, 1985.

GLASER, Barney; STRAUSS, Anselme. The discovery of grounded theory: strategies for qualitative research. Chicago: Aldine, 1967.

HERVIEU-LÉGER, Danièle. Le pèlerin et le converti: la religion en mouvement. Paris: Flammarion, 1999.

LAMBERT, Yves. Dieu change en Bretagne: la religion à Limerzel, de 1900 à nos jours. Paris: Ed. du Cerf, 1985.

LEANDRO, Maria Engrácia. A saúde no prisma dos valores da modernidade. Trabalhos de Antropologia e Etnologia, Porto, v. 41, n. 3-4, p. 67-93, 2001. 
LEANDRO, Maria Engrácia. Au-delà des apparences: les portugais face à l'insertion sociale. Paris: L'Harmattan, 1995.

LEANDRO, Maria Engrácia. Esperança no mundo de hoje. Brotéria, Lisboa, v. 161, p. 23-51, 2005.

LEANDRO, Maria Engrácia; LEANDRO, Ana Sofia da Silva. Da saúde e bem-estar/mal-estar ao termalismo. Sociologia: Revista da Faculdade de Letras da Universidade do Porto, Porto, v. 30, p. 75-96, 2015.

LÉVI-STRAUSS, Claude. As estruturas elementares do parentesco. Petrópolis: Vozes, 1982.

LIMA, Raquel dos Santos Sousa. "É como se fosse Santa Rita": processos de simbolizaçáo e transformaçōes rituais na devoçáo à santa dos impossíveis. 2014. Tese. (Doutorado em Antropologia Social) - Universidade Federal do Rio de Janeiro, Rio de Janeiro, 2014.

LIMA, Raquel dos Santos Sousa. Sobre presença e representação nas imagens dos santos católicos: considerações a partir de um estudo sobre a devoçấo à Santa Rita. Religiäo \& Sociedade, Rio de Janeiro, v. 35, n. 1, p. 139-163, jun. 2015.

MARTIN, David. The religious and the secular: studies in secularization. London: Routledge \& Kegan Paul, 1969.

MENEZES, Renata de Castro. A dinâmica do sagrado. Rio de Janeiro: Relume Dumará, 2004.

TEIXEIRA, Alfredo (org.). Identidades religiosas em Portugal: representaçóes, valores e práticas. Lisboa: Universidade Católica Portuguesa, 2011.

THOMAS, Louis-Vincent. La mort. Paris: PUF, 1988.

TORGA, Miguel. A criação do mundo. Coimbra: Gráfica de Coimbra, 1969. v. 1. 
VILAÇA, Helena. Da Torre de Babel às Terras Prometidas: pluralismo religioso em Portugal. Porto: Afrontamento, 2006.

WEBER, Max. Essais sur la théorie de la science. Paris: Presse Pocket, 1992.

Recebido em: 23/04/2019

Aprovado em: 20/01/2020

Debates do NER, Porto Alegre, ano i9, N. 36, P. 335-363, Ago./Dez. 20 i9 


\section{ENSAIO FOTOGRÁFICO}

